\title{
PENGALAMAN PEROKOK RENDAH TAR DAN NIKOTIN DI KOTA MALANG
}

\author{
Smoker Experience In Low-Tar And Nicotine Malang \\ Kumboyono $^{1}$, Junaiti Sahar ${ }^{2}$, Wiwin Wiarsih ${ }^{3}$ \\ ${ }^{1}$ Program Studi Ilmu Keperawatan Fakultas Kedokteran Universitas Brawijaya \\ J1. Veteran Malang 65145 \\ ${ }^{2,3}$ Fakultas Ilmu Keperawatan Universitas Indonesia \\ 1)e-mail: kumbo_yono05@yahoo.com atau kumboyono05@gmail.com \\ ${ }^{2)}$ e-mail: junsr@ui.ac.id
}

\begin{abstract}
ABSTRAK
Kehadiran rokok rendah tar dan nikotin (mild) menimbulkan asumsi bahwa rokok jenis ini lebih ramah terhadap kesehatan. Hal ini dikaitkan dengan PP No. 38 tahun 2000 pasal 4 ayat 1, menyebutkan batasan kadar maksimal per batang rokok untuk tar adalah $20 \mathrm{mg}$ dan nikotin 1,5 mg. Pembatasan ini dimaksudkan untuk menurunkan kandungan kadar tar dan nikotin yang lebih tinggi pada rokok kretek yang selama ini telah beredar di Indonesia. Penelitian ini bertujuan mendeskripsikan makna pengalaman perokok dalam mengkonsumsi rokok mild di Kota Malang. Penelitian dilakukan dengan desain fenomenologi pada tujuh partisipan. Penelitian menghasilkan empat tema yaitu: alasan merokok mild; perubahan yang terjadi setelah menjadi perokok mild; makna kebiasaan merokok; jenis dan strategi layanan yang dibutuhkan untuk berhenti merokok. Kesimpulan penelitian ini ialah perokok menilai rokok rendah tar dan nikotin merupakan rokok ringan sehingga memacunya untuk terus menerus merokok dengan hisapan yang lebih dalam atau lebih banyak. Pemerintah disarankan untuk melarang pencantuman label mild dan sejenisnya yang dapat dipersepsikan secara keliru oleh perokok.
\end{abstract}

Kata kunci: berhenti merokok, fenomenologi, perokok, rokok mild

\begin{abstract}
The mild cigarette led to the assumption that this cigarette has a lower risk for health. This matter is related to PP No. 38 year 2000 section 4 article 1, mentioning maximal rate constrain per bar smoke for tar is 20 nicotine and $\mathrm{mg} \mathrm{1,5} \mathrm{mg.} \mathrm{This} \mathrm{demarcation} \mathrm{is} \mathrm{meant} \mathrm{to} \mathrm{degrade} \mathrm{rate} \mathrm{content} \mathrm{of} \mathrm{tar} \mathrm{higher} \mathrm{level}$ nicotine and cigarette of kretek which during the time have circulated in Indonesia. This phenomenological study was aimed to describe the meanings of smoker's experiences regarding the mild cigarettes consumption in Malang. Seven participants were selected. The results showed four themes: smoking reasons; changes that happen after smoking; meanings in relation with smoking habit; strategies needed to stop smoking. This study concluded that smokers believed the mild cigarettes were categorized in light cigarettes, and as a consequence, smokers have more interest in smoking continuously and inhaling more deeply. The government is suggested to stop putting the label of mild/other similar labels in a cigarettes pack which could be perceived incorrectly by smokers.
\end{abstract}

Keywords: mild cigarettes, phenomenology, smokers, stop smoking

\section{LATAR BELAKANG}

Berbagai usaha dilakukan pemerintah untuk mengurangi jumlah perokok dan konsumsi rokok di Indonesia guna mengantisipasi dampak negatif merokok. Salah satu upaya tersebut adalah penerbitan Peraturan Pemerintah (PP) No. 38 tahun 2000 mengenai perubahan atas PP No. 81 tahun 1999 tentang pengamanan rokok bagi kesehatan. PP No. 38 tahun 2000 pasal 4 ayat 1, menyebutkan batasan kadar maksimal per batang rokok untuk tar adalah $20 \mathrm{mg}$ dan nikotin 1,5 mg. Pembatasan ini dimaksudkan untuk menurunkan kandungan kadar tar dan nikotin yang lebih tinggi pada rokok kretek yang selama ini telah beredar di Indonesia. 
Pembatasan kadar tar dan nikotin yang dilakukan pemerintah justru mengakibatkan pergeseran pola produksi dan konsumsi rokok di Indonesia. Sebagai respon terhadap PP No. 38 tahun 2000 tersebut, maka produsen rokok mulai meningkatkan produksi serta promosi rokok dengan kadar tar dan nikotin lebih rendah yang dikenal dengan rokok mild/light/ low tar (Siswono, 2000; Ardi, 2001). Publikasi data oleh salah satu produsen rokok besar di Jawa Timur pada tahun 2000 menyebutkan proporsi konsumsi rokok kretek dengan rokok mild ialah 77,8\%: 22,2\% (Ardi, 2001). Nurwatie (2004) meneliti perokok pria usia 15 hingga 54 tahun di Kota Malang menemukan perbandingan antara perokok kretek dengan mild sebanyak 53\%: $47 \%$. Berdasarkan data di atas terlihat kecenderungan rokok kretek mulai tersaingi dengan kehadiran rokok mild khususnya di Kota Malang.

Kecenderungan pergeseran rokok kretek kepada rokok mild mencerminkan potensi peningkatan konsumsi rokok jenis ini. Nurwatie (2004) menemukan kecenderungan $70 \%$ perokok kretek akan beralih ke rokok mild jika rokok kretek tidak diproduksi lagi. Informasi tersebut mengindikasikan keinginan kuat perokok di Kota Malang untuk tetap merokok. Motivasi kuat untuk tetap merokok akan menghalangi usaha berhenti merokok secara total (Whetherall, 2006). Sedangkan konsumsi rokok mild tidak berbanding lurus berkurangnya dengan buruk merokok. Hal ini disebabkan zat kimia beracun rokok tetap masuk dan terakumulasi dalam tubuh perokok baik cepat maupun lambat. Oleh karena itu keputusan perokok untuk mengkonsumsi rokok mild sebagai pengganti rokok kretek merupakan suatu perilaku yang tetap membahayakan kesehatan. Bertolak dari fenomena tersebut maka perlu diketahui pengalaman perokok dalam mengkonsumsi rokok mild di Kota Malang melalui studi kualitatif.

\section{METODE}

Penelitian ini merupakan studi kualitatif fenomenologis. Partisipan diseleksi menggunakan teknik purposif dengan karakteristik: perokok yang hanya mengkonsumsi jenis rokok mild minimal dalam enam bulan terakhir saat penelitian dilakukan; memahami dan mampu berbahasa Indonesia; menyatakan kesediaan menjadi partisipan dengan menandatangani persetujuan penelitian. Partisipan yang berperan serta dalam penelitian ini sebanyak tujuh orang. Jumlah partisipan ini telah memenuhi kondisi saturasi data.

Penelitian ini telah mengaplikasi prinsip etik (otonomy, beneficience, maleficience, dan justice) serta telah lulus uji etik dari komite etik Fakultas Ilmu Keperawatan Universitas Indonesia. Penelitian dilakukan di Kota Malang sejak awal Februari hingga Juli 2007. Data dikumpulkan dengan teknik wawancara mendalam. Rata-rata waktu wawancara untuk setiap partisipan adalah 30-40 menit. Proses wawancara direkam menggunakan tape recorder dan catatan lapangan. Kegiatan wawancara pada satu orang partisipan diakhiri pada saat semua informasi yang dibutuhkan telah diperoleh sesuai tujuan penelitian. Pembuatan transkrip wawancara dilakukan dengan memutar kembali kaset hasil rekaman dan diketik kata demi kata menggunakan program microsoft word. Hasil catatan lapangan berupa respon non verbal partisipan, diintegrasikan dalam transkrip sesuai saat kejadian respon tersebut selama proses wawancara. Data transkrip kemudian dianalisis secara manual dengan metode Colaizzi melalui tahapan-tahapan (1978, dalam Streubert \& Carpenter, 1999). Proses analisis data dilakukan untuk mengidentifikasi kluster tema yang terdiri atas kata kunci, kategori, sub tema, dan tema penelitian.

\section{HASIL DAN PEMBAHASAN}

Tema: Alasan Mengkonsumsi Rokok Mild 
Deskripsi alasan mengkonsumsi rokok mild mencerminkan alasan yang menyebabkan partisipan berpindah selera atau hanya memilih mengkonsumsi rokok mild. Alasan mengkonsumsi rokok mild meliputi alasan utama dan penunjang.

Alasan utama merupakan alasan yang paling dominan dalam menentukan pilihan partisipan terhadap rokok mild: rokok terasa ringan sewaktu dihisap, berkurangnya riwayat keluhan kesehatan yang sebelumnya dirasakan sebagai akibat dari merokok kretek, rendahnya kadar tar dan nikotin dalam sebatang rokok dan pengaruh bergaul dengan perokok mild. Ilustrasi tentang alasan-alasan tersebut tercermin pada pernyataan berikut ini:

“.....coba-coba rokok yang mana yang enak.....rokok yang paling cocok bagi saya adalah mild....enak gitu.... agak ringan" (P.6).

"waktu merokok kretek...lama kelamaan....terjadi semacam degup jantung ga begitu normal.....trus leher sampai kepala bagian belakang itu timbul nyeri....disertai pusing....itu menyebabkan saya pindah ke rokok mild" (P.2).

“.....katanya kadar nikotinnya.....lebih kecil dari rokok yang besarbesar....kandungan tar atau apalah juga tidak terlalu banyak" (P.7).

"perpindahan ke rokok mild itu seiring pergaulan, waktu itu sekitar SMA, ketemu temen-temen perokok juga, kebetulan rokok mereka itu model kayak rokok mild gitu” (P.5).

Alasan penunjang merupakan alasan yang mendukung keberlangsungan partisipan untuk terus mengkonsumsi rokok mild, misalnya: ketagihan, cita rasa rokok berupa kuantitas asap sedang dan rokok terasa ringan, keterjangkauan ekonomi, kemudahan akses, ukuran rokok, serta kadar tar dan nikotin lebih rendah. Berikut ungkapanungkapan partisipan terkait tema tersebut:

"Akhirnya juga ketagihanlah ibaratnya, sekarang sudah terbiasa dengan rokok mild" (P.7).

“.....mild ini asapnya sedang” (P.6).

“.....kretek kalo dihisap itu agak berat, kalo rokok lights ini enteng" (P.3).

"...harganya terjangkau....bisa beli ngecer". (P.1).

".....gampang di kios-kios, di warungwarung di daerah ini hampir semua ada stoknya untuk produk mild" (P.2).

"rokoknya agak kecil, agak sederhana gitu, jadi pas di tangan" (P.6).

"dilihat dari kandungan tar kretek $30 \mathrm{mg}$, mild 15 mg ya hampir setengahnya.....untuk nikotin di kretek 1,8 mg, mild 1,0..... Iha itu juga kira-kira hampir setengahnya" (P.2).

\section{Tema: Perubahan Yang Terjadi Setelah Menjadi Perokok Mild}

Perubahan yang terjadi setelah menjadi perokok mild memberikan gambaran tentang arti reaksi-reaksi yang muncul segera setelah mengkonsumsi rokok mild. Setelah mengkonsumsi rokok mild, perokok merasakan adanya perubahan yang terjadi pada masalah kesehatan fisik dan pola merokok.

Perokok yang mempunyai masalah kesehatan fisik akibat menghisap jenis rokok kretek merasakan bahwa keluhan kesehatan tersebut menjadi lebih ringan atau hilang, serta frekuensi sakit menjadi lebih berkurang setelah mengkonsumsi rokok mild. Berikut contoh pernyataan partisipan terkait kategori tema tersebut:

"kalo mild itu ngga terlalu pekat di lidah jadi nafsu makan biasa-biasa saja” (P.2). 
“.....mengkonsumsi rokok lights hampir dua tahun ini, tidak pernah merasakan sakit dada sebelah kiri lagi” (P.4).

“.....kretek itu kan sering batuk.....kalau mild jarang” (P.6).

Pola merokok yang berubah meliputi jumlah konsumsi, kedalaman hisapan, waktu menghabiskan sebatang rokok dan upaya untuk selalu merokok. Kategori-kategori tema di atas terungkap dalam pernyataanpernyataan berikut:

“.....kretek satu bungkus isi 12 batang bisa sampai tiga hari, kalo mild itu 16 batang paling lama dua hari.....16 batang dalam sehari itu paling cepat” (P.3).

“.....rokok filter sehari itu habis dua pak isi 12 batang.....sekarang satu pak mild yang isinya 16 batang itu habisnya dua hari....rokok dinyalakan langsung dihisap....sreeeet dalem.....itu kebiasaan saya” (P.7).

“.....mild itu kan paling ndak sampe 10 menit sudah habis....10 menitan lah habisnya sebatang.....kalo filter itu 15 sampe 25 menit, tapi kalo seperti kretek itu 25 sampe 35 menit" (P.7).

“.....ga punya uang untuk beli rokok, saya punya pengalaman....penghasilan pas-pasan, hanya cukup buat makan anak dan istri aja, bisa ngga ngerokok tuh. Jadi kalo mau ngerokok tinggal nongkrong aja sama temen-temen yang ngerokok, itu kan nanti dikasih sama mereka. Nah udah habis satu ya sudah pergi”, (P.7).
Tema: Makna Mengonsumsi Rokok Mild

Makna mengkonsumsi rokok mild mendeskripsikan inti pengalaman perokok dalam mengkonsumsi rokok rendah tar dan nikotin. Tiga tema makna yang dikemukakan perokok setelah dan selama mengkonsumsi rokok mild yaitu suasana hati, fungsi sosial dan kebiasaan merokok.

“.... bisa melihat pikiran lebih enak ..... lebih tenang ..... lebih segar .... lebih fresh ..... lebih gagah, lebih macho begitulah" (P.7).

“makna merokok itu.....lebih ke pergaulan dan persahabatan.....misalkan kita punya temen yang baru dari rokok, sering kumpul...kedekatan dan keakraban itu bisa meningkat” (P.5).

"Pisah dari rokok itu nomor dua, nomor duanya nyawa saya....kalau misalkan pisah itu kayak mau gila aja gitu, rasanya mau hancur.....kalau ngerokok itu rasanya hidup itu ada....." (P.6).

\section{Tema: Jenis Layanan Dan Strategi Yang Dibutuhkan Untuk Berhenti Merokok}

Jenis layanan kesehatan yang dibutuhkan perokok tergolong pada program berhenti merokok. Program berhenti merokok yang dibutuhkan meliputi pemberian informasi dampak negatif merokok, cara-cara serta pemberian terapi berhenti merokok. Beberapa contoh pernyataan partisipan mengenai kategori tema tersebut antara lain:

“.....menjelaskan dampak negatif rokok itu bagaimana” (P.4).

“....diberi pengetahuan, gambaran apalagi fotonya” (P.7). 
“.....memberi solusi bagaimana caranya berhenti, .....dengan terapi-terapi tertentu untuk memperlancar berhenti merokok" (P.2).

Pelaksanaan program tersebut membutuhkan pendekatan-pendekatan yang tercermin pada strategi layanan berhenti merokok. Strategi yang dibutuhkan perokok teridentifikasi dalam bentuk layanan individu dan masyarakat. Layanan individu yang dibutuhkan berupa pendekatan personal dan identifikasi motivasi untuk berhenti merokok. Layanan masyarakat berupa sosialisasi program anti rokok perlu diperluas pada semua kelompok masyarakat termasuk kelompok usia sekolah. Keberadaan kategori tema layanan indvidu tersebut terungkap pada pernyataan berikut ini:

\section{“.....mungkin dengan mendatangi semacam kayak gini.....” (P.2). \\ “.... gimana caranya pendekatan ke orang”(P.7).}

“.....orang yang datang ke fasilitas kesehatan itu harus sudah punya niat untuk berhenti merokok" (P.7). "sebenarnya dari kesadaran pribadi saja.....dari dalam hati kita sendiri pengen berhenti atau tidak" (P.1).

“......sosialisasi.....kampanye anti rokok di sekolah" (P.1).

Tema-tema di atas merupakan bagian dari 17 tema yang ditemukan dalam penelitian ini. Gambaran keseluruhan tema selengkapnya ada pada skema 1 .

Penilaian perokok terhadap rokok mild memperkuat kekhawatiran akan timbulnya salah persepsi terhadap rokok rendah tar dan nikotin. World Health Organization (WHO) melalui Framework Convention on Tobacco Control (FCTC) pada tahun 2003 menyebutkan pada pasal 11 ayat 1a melarang penggunaan istilah pelabelan rokok ber-tar dan nikotin rendah (mild/lights/low tar) karena dianggap dapat menyesatkan masyarakat. Hal ini dijelaskan juga oleh Saputro (2003) bahwa ada anggapan di kalangan perokok mild atau lights yang menyatakan seakan-akan mengkonsumsi rokok jenis rendah tar dan nikotin lebih aman untuk kesehatan. Selanjutnya Saputro mengemukakan menghisap rokok mild tidak akan membantu mengurangi dampak buruk rokok bagi kesehatan.

Alasan ketagihan menandakan bahwa merokok jenis apapun termasuk jenis rokok mild, tetap saja menimbulkan efek adiksi (Husaini, 2006). Hasil studi ini menguatkan

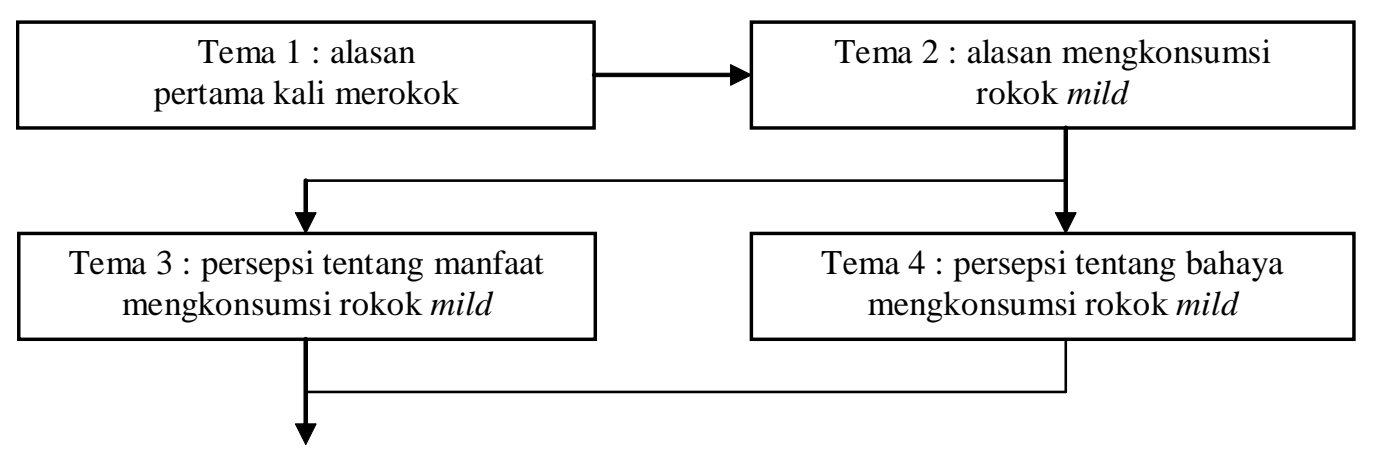




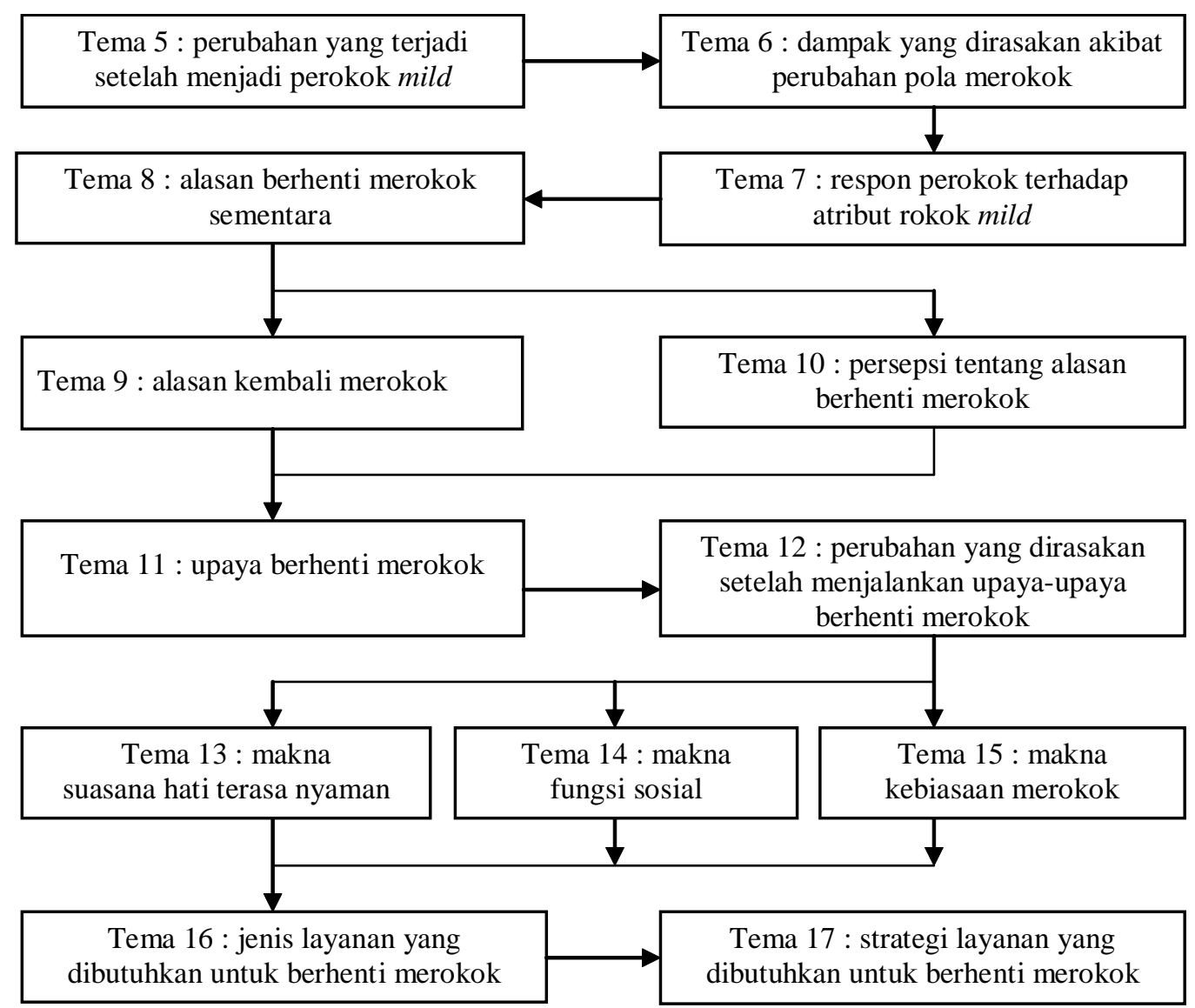

Gambar 1.Skema tema pengalaman perokok dalam mengkonsumsi rendah tar dan nikotin di Kota Malang

Alasan ketagihan menandakan bahwa merokok jenis apapun termasuk jenis rokok mild, tetap saja menimbulkan efek adiksi (Husaini, 2006). Hasil studi ini menguatkan pendapat Mu'tadin (2002) yang menyatakan bahwa nikotin sebagai zat adiktif sekecil apapun kadarnya, akan mampu memaksa perokok untuk terus menerus merokok. Sejalan dengan pendapat tersebut, Waney (2002) menjelaskan stimulasi nikotin akan menimbulkan rasa nikmat sehingga menyebabkan seseorang ketagihan merokok.

Alasan yang menunjang perokok untuk terus mengkonsumsi rokok mild adalah keterjangkauan harga, ukuran yang lebih kecil sehingga pas di tangan, dan kemudahan akses. Hal ini sesuai dengan hasil penelitian Nurwatie (2004) yang menyebutkan bahwa perokok mild di Kota Malang bersedia menerima keberadaan rokok mild karena distribusi lancar, harga terjangkau dan sesuai selera. Fakta kemudahan akses dan keterjangkauan harga ini bertentangan dengan FCTC pasal 16 ayat 3 yang menyebutkan adanya larangan penjualan rokok dalam bentuk eceran/batangan. Sebaliknya pernyataan larangan serupa, tidak ditemukan pada PP No. 19 Tahun 2003. Pembatasan ini bermaksud mencegah anak/ remaja serta orang berpenghasilan rendah untuk membeli dan memudahkan akses bagi mereka terhadap rokok (Aditama, 2007).

Kemudahan akses rokok juga tidak bisa dilepaskan dari kebijakan pemerintah dalam PP No. 19 Tahun 2003 yang tidak mengatur adanya larangan penjualan rokok pada kelompok usia anak/remaja. Hasil penelitian menunjukkan bahwa partisipan memiliki pengalaman merokok untuk pertama kalinya bervariasi mulai umur 8 hingga 18 tahun, hal ini mengindikasi adanya akses bagi anak/ remaja dalam membeli rokok. Fakta tentang 
kemudahan akses ini bertentangan dengan FCTC pasal 16 ayat 1 , dimana pada pasal tersebut dengan tegas disebutkan larangan penjualan rokok pada anak di bawah usia 18 tahun. Pender, Murdaug dan Parsons (2002) menyebutkan anak/remaja adalah kelompok usia kritis dalam pembentukan perilaku sehat karena anak dan remaja belum memiliki ketrampilan kognitif yang cukup dalam berpikir tentang resiko perilaku kesehatan yang menjadi pilihannya.

Perubahan-perubahan yang terjadi segera setelah mengkonsumsi rokok mild adalah persepsi individu terhadap menurunnya kuantitas dan kualitas masalah kesehatan fisik yang terjadi sewaktu mengkonsumsi rokok kretek. Persepsi berkurang atau hilangnya masalah kesehatan ini akan memacu perokok untuk tetap mempertahankan perilaku tidak sehat dengan merokok mild. Hal ini sesuai dengan teori Health Belief Model dari Becker (1977, dalam Pender, Murdaug, \& Parsons, 2002) yang menyebutkan bahwa perilaku akan dianggap positif jika tidak menimbulkan dampak yang serius terhadap kesehatan. Perubahan positif yang dirasakan perokok tersebut menyebabkan efek berantai terhadap pola merokok mild.

Penelitian ini menemukan adanya perbedaan pola merokok dalam segi jumlah konsumsi rokok mild bila dibandingkan dengan rokok kretek yaitu lebih banyak atau lebih sedikit. Respon mengkonsumsi lebih banyak dijumpai pada partisipan yang menghisap rokok mild dengan alasan terasa ringan dan riwayat keluhan kesehatan yang dirasakan selama mengkonsumsi rokok kretek menjadi hilang. Sedangkan pada kelompok partisipan yang mengkonsumsi rokok mild dengan jumlah lebih sedikit, ditemukan kebiasaan menghisap rokok mild lebih dalam. Hal ini memperkuat asumsi Saputro (2003) dan Tandra (2004) yang menyatakan untuk memenuhi kadar nikotin yang tetap konstan dalam darah, maka perokok mild akan lebih banyak atau lebih dalam saat menghisap asap rokok.
Respon selalu berupaya untuk merokok ditemukan pada hampir seluruh kelompok perokok mild baik yang menghisap jumlah rokok lebih banyak maupun lebih sedikit. Perokok selalu berusaha mencari alternatif solusi untuk tetap bisa merokok meskipun tidak memiliki dana untuk membeli rokok (Siswono, 2004). Kondisi ini diperkuat oleh pendapat Mu'tadin (2002); Waney (2002) tentang ketergantungan rokok, serta menunjang hasil penelitian Whetherall (2006) yang menjelaskan bahwa perokok menjadi ketagihan akibat efek adiktif nikotin sehingga akan terus berupaya untuk mendapatkan rokok.

Makna suasana hati terasa nyaman dan fungsi sosial berupa perasaan lebih hidup, gaya, santai serta gaul yang ditemukan dalam penelitian ini, menguatkan hasil penelitian Rahmawatie (2002). Rahmawatie dalam studi semiotika tentang iklan rokok mild menemukan bahwa dengan merokok mild, seorang perokok akan menjadi pribadi yang lebih tenang, aktif, dinamis, mempunyai citacita, keinginan, kesabaran dan kegigihan dalam meraih semua yang telah menjadi pilihan hidupnya. Hasil serupa juga didapatkan pada penelitian yang dilakukan oleh Baharudin (2004) dan Mesu (2004) yaitu merokok mild mendatangkan makna positif dalam diri perokok berupa perasaan lebih percaya diri dan lebih gaul.

Hasil penelitian berupa makna suasana hati terasa nyaman dan fungsi sosial menunjukkan adanya gangguan dalam proses tumbuh kembang. Partisipan memiliki riwayat merokok sejak usia anak hingga remaja (818 tahun). Adingsih (2006) menyebutkan bahwa anak dan remaja merupakan masa pencarian identitias diri yang sangat rentan terhadap pengaruh lingkungan. Maknamakna yang dipersepsikan perokok tidak terlepas dari pengaruh lingkungan terutama iklan rokok. Baharudin (2004) dan Mesu (2004) menjelaskan bahwa dalam pemasaran hasil produksinya ke masyarakat, produsen rokok rendah mild dengan sengaja 
menciptakan suatu makna tertentu melalui berbagai media untuk membangun citra merek rokok produknya. Perokok yang satu dengan lainnya memiliki bahasa-bahasa berbeda dalam menangkap dan menginterpretasikan pesan makna tersembunyi ini, namun perbedaan bahasa tersebut tetap berada dalam lingkup makna citra merek yang diinginkan produsen (Rahmawatie, 2002).

Merokok memiliki makna kebiasaaan merokok bagi perokok yang menjadikan rokok mild sebagai sarana untuk mengurangi ketergantungan terhadap rokok. Makna ini menunjukkan perokok berkeinginan untuk terus merokok. Perokok tersebut berasumsi dengan beralih kepada rokok mild maka kesehatannya tetap bisa terjaga tanpa harus meninggalkan kebiasaan merokok secara total. Asumsi ini bertentangan dengan penelitian yang telah membuktikan bahwa berapapun kadar tar dan nikotin yang dikonsumsi perokok, akan tetap membahayakan kesehatan tubuhnya. Penelitian di Inggris tahun 2000 menyebutkan tidak ada perbedaan bermakna antara angka kesakitan dan kematian pada kelompok perokok yang mengkonsumsi rokok dengan kandungan tar lebih dari $15 \mathrm{mg} /$ batang dengan kurang dari $15 \mathrm{mg} / \mathrm{batang}$. Perbedaan bermakna baru ditemukan bila membandingkan proporsi kesakitan dan kematian di atas dengan kelompok bukan perokok. Pendapat tersebut dikuatkan penelitian di Amerika Serikat oleh Prabhat dan Chaloupka (2000) yaitu pada kurun waktu 1970 hingga 2000, angka kematian yang berhubungan dengan merokok tidaklah turun meskipun konsumsi rokok mild semakin meningkat dan meluas.

Jenis layanan kesehatan yang ditemukan tergolong dalam program berhenti merokok. Perokok berdasarkan pengalamannya terlihat hanya memerlukan pemberian informasi tentang bahaya dan teknik-teknik untuk berhenti merokok. Kebutuhan ini belum lengkap apabila ditinjau dari sudut pandang keperawatan komunitas karena program berhenti merokok hanya ditujukan pada individu perokok saja. Helvie (1998) menyebutkan tiga program komprehensif untuk menanggulangi kebiasaan merokok yaitu smoking prevention, cessation dan protection. Tindakan smoking prevention ditujukan untuk mencegah seseorang menjadi perokok, smoking cessation untuk membantu perokok berhenti merokok dan mencegah kekambuhan serta smoking protection guna melindungi orang-orang yang tidak merokok dari asap rokok. Bukti efektifitas keterpaduan program smoking prevention, cessation dan protection dalam penanggulangan perilaku merokok dijelaskan Baldwin, Rothman dan Hertel (2006) yaitu peningkatan keberhasilan dan kepuasan individu secara mandiri dalam usaha berhenti merokok. Berdasarkan paparan di atas disimpulkan keterpaduan tiga program tersebut diperlukan dalam inisiasi dan pemeliharaan perilaku berhenti merokok.

Strategi pelayanan program berhenti merokok dibutuhkan untuk mendekatkan program berhenti merokok. Kebutuhan perokok terhadap strategi layanan kesehatan yang teridentifikasi dalam penelitian ini terdiri atas dua hal yaitu pelayanan secara individual dan masyarakat. Strategi pelayanan individual yang dibutuhkan berupa pendekatan personal dan identifikasi motivasi perokok untuk berhenti merokok. Strategi ini dibutuhkan mengingat setiap perokok adalah individu yang unik sehingga perlu didekati secara pribadi untuk membantunya berhenti merokok (Husaini, 2006). Pendekatan secara massal berupa kegiatan sosialisasi seperti kampanye anti rokok diperlukan untuk memperkuat layanan individual. Dukungan masyarakat terhadap layanan individual dalam program berhenti merokok sesuai dengan penelitian Prabhat dan Chaloupka (2000). Prabhat dan Chaloupka menyebutkan dari 5 orang perokok di Amerika Serikat yang memiliki keyakinan untuk berhenti merokok dalam lima tahun, ternyata kurang dari 2 orang perokok saja 
yang benar-benar mampu berhenti merokok karena ketiadaan faktor kebijakan publik yang mendukung. Lebih lanjut Canadian Nurses Association (2001) menyebutkan bahwa usaha behenti merokok secara individual akan lebih efektif bila disertai kebijakan publik tentang tembakau dan produk olahannya yang lebih menyeluruh seperti regulasi dibidang penanaman tembakau, produksi, distribusi, promosi, penjualan rokok serta kawasan bebas rokok.

\section{KESIMPULAN DAN SARAN}

Perokok memiliki pengalaman yang bervariasi dalam mengkonsumsi rokok mild. Perokok menilai rokok mild adalah rokok ringan, sehingga memacunya untuk terus menerus merokok dengan hisapan yang lebih dalam atau lebih banyak. Kondisi tersebut mengindikasikan rokok mild tetap menimbulkan efek adiksi yang dapat membahayakan kesehatan.

Saran yang dapat diberikan perawat komunitas kepada pemerintah terkait program smoking prevention, cessation dan protection secara komprehensif guna menanggulangi perilaku merokok adalah: melarang pencantuman label mild, lights, ultra lights dan sejenisnya yang dapat dipersepsikan secara keliru oleh perokok; merubah desain peringatan bahaya merokok pada bungkus rokok dalam bentuk gambar/ foto penyakit akibat merokok dan mencatumkannya pada sisi besar bungkus rokok; larangan kegiatan promosi rokok secara menyeluruh; larangan penjualan rokok pada anak di bawah 18 tahun; izin perdagangan rokok untuk membatasi daerah pemasaran rokok; larangan penjualan rokok dalam betuk batangan; menetapkan instansi yang bertangung jawab secara operasional dalam kegiatan monitoring dan evaluasi secara berkala, termasuk pemberian sanksi/ denda terhadap pelanggaran peraturan pemerintah tentang pengamanan rokok bagi kesehatan.

\section{DAFTAR PUSTAKA}

Adiningsih, U. 2006. Mencegah Bahaya Rokok pada Anak dan Remaja. http:// w w w. s u r y a . c o . i d / naskah.php?id=9256\&rid=12. Diperoleh tanggal 8 Januari 2007.

Aditama, T.Y. 2007. Rokok di Sinetron. <http:/ /www.kalbe.co.id/file/cdk/files/ 147_15rokokdisinetron.pdf $>$. Diperoleh tanggal 8 Maret 2007.

Ardi, Y. 2001. Kampanye Rokok Tar Rendah Himpit Industri Kretek. http: // ww w. bis nis.com/serviet/ page?_pageid=268. Diperoleh tanggal 8 Januari 2007.

Baharuddin, R. 2004. Strategi Citra Merek Sampoerna a Mild: Bentuk-Bentuk Pencitraan Iklan Billboard a Mild Versi Origami. http://digilib.unikom. ac.id/ go.php?id=jbptunikompp-gdl-s1-2004rezabaharu-279. Diperoleh tanggal 20 Juni 2007.

Baldwin, A.S., Rothman, A.J., \& Hertel, A.W. 2006. Specifiying The Determinants of The Limitation and Maintenance of Behavior Change: An Examination of Self-Efficacy, Satisfaction and Smoking Cessation. Journal Health Psychology. 25(5).

Canadian Nurses Association. 2001. Tobacco: The Role of Health Professionals in Smoking Cessation Joint Statement. http://www.cna-nurses.ca/CNA/docu$\mathrm{ment} / \mathrm{pd}$ / p u bli c a t i on s/ PS49_Reducing_use_Tobacco_June_2001_epdf. Diperoleh tanggal 15 Januari 2007.

Creswell, J.W. 1998. Qualitative Inquiry \& Research Design: Choosing Among Five Traditions. Thousand Oaks: Sage Publications, Inc.

Helvie, O.C. 1998. Advanced Practice Nursing in The Community. Thousands Oaks: Sage Publications.

Husaini, A. 2006. Tobat Merokok: Rahasia dan Cara Empatik Berhenti Merokok (Alih Bahasa: Narulita, S.J.). Depok: Pustaka Iman. 
Mesu, Y.D. 2004. Pengaruh Pelaksanaan Publisitas Terhadap Brand Image Rokok a Mild pada PT HM Sampoerna: Studi Banding pada Mahasiswa Fakultas Ekonomi Unikom Bandung. http:// d i g i l i b. u n i k o m.a c. i d / go.php?id=jbptunikompp-gdl-s1-2004yulianadom-605. Diperoleh tanggal 20 Juni 2007.

Mu'tadin. 2002. Remaja dan Rokok. http:// www.e-psikologi.com/remaja/ 050602. Diperoleh tanggal 16 Maret 2007.

Nurwatie, D.I. 2004. Analisis Sikap Konsumen Terhadap Rokok Mild Sebagai Produk Alternatif di Kotamadya. Malang. http:// digilib.brawijaya.ac.id/virtuallibrary/ $\mathrm{mlg}$ _serial/Pdf\%20Material/ $\mathrm{Jurn}$ a $1 \% 20 \mathrm{Pasc}$ a s a j a / peri laku $\% 20 \mathrm{kons}$ u men/ donna\%20indah\%20nurwatie. pdf. Diperoleh tanggal 9 Januari 2007.

Presiden Republik Indonesia. 1999. Peraturan Pemerintah Republik Indonesia Nomor 81 Tahun 1999 Tentang Pengamanan Rokok Bagi Kesehatan. http://www. dprin.go.id/regulasi/1999/10/pp8199.pdf. Diperoleh tanggal 22 Januari 2007.

Presiden Republik Indonesia. 2000. Peraturan Pemerintah Republik Indonesia Nomor 38 Tahun 2000 Tentang Pengamanan Rokok Bagi Kesehatan. http://www. pom.go.id/public/hukum_perundangan /pdf/napza_38.pdf. Diperoleh tanggal 22 Januari 2007.

Presiden Republik Indonesia. 2003. Peraturan Pemerintah Republik Indonesia Nomor 19 Tahun 2003 Tentang Pengamanan Rokok Bagi Kesehatan. http://www. pom.go.id/public/hukum_perundangan/ pdf/napza_53.pdf. Diperoleh tanggal 22 Januari 2007.

Pender, N.J., Murdaug, C.L., \& Parsons, M.A. 2002. Health Promotion in Nursing Practice. $4^{\text {th }}$ ed. Upper Saddle River: Prentice Hall.
Prabhat, J., Chaloupka, F.J. 2000. Meredam Wabah: Pemerintah dan Aspek Ekonomi (Alih Bahasa: Adioetomo, S. M.). Washington: The World Bank.

Rahmawatie, R. 2002. Studi Semiotika pada Iklan Rokok Star Mild di Televisi. http:/ / library.gunadarma.ac.id/ go.php?id=jiptumm-gdl-sl-2002-rosyidah -4940-semiotika. Diperoleh tanggal 20 Juni 2007.

Saputro, E.P. 2003. Rokok Versus Kesehatan Publik: Refleksi Hari Kesehatan Sedunia. http://www.antirokok.or.id/ berita/berita_refleksi.htm. Diperoleh tanggal 10 Januari 2007.

Siswono. 2000. Ramai-Ramai Produksi "Rokok Sehat". http://www.eksekutif. com/berita/artikel.html?aid $=589$. Diperoleh tanggal 22 Januari 2007.

Siswono. 2004. Lingkaran Kemiskinan Para Penghisap Rokok. <http://www. kompas.com/kesehatan/news/0405/31/ 094609.htm>. Diperoleh tanggal 10 Januari 2007.

Sumarno, S.B., Kuncoro, M., 2004. Struktur Kinerja dan Kluster Industri Rokok Kretek Indonesia oleh http://www. mudrajad.com/upload/journal_strukturkinerja-kluster-industri-rokok. pdf. Diperoleh tanggal 15 Januari 2007.

Streubert, H.J., Carpenter, D.R. 1999. Qualitative Research in Nursing: Advancing The Humanistic imperative. $2^{\text {nd }}$ ed. Philadelphia: Lipincott Williams $\&$ Wilkins.

Tandra, H. 2004. Merokok dan Kesehatan. <http://www.antirokok.or.id/berita/ berita_rokok_kesehatan.htm>. Diperoleh tanggal 10 Januari 2007.

Waney, A. 2002. Pasien Skizofrenia Cenderung Gemar Merokok. http:// www.kompas.com/kesehatan/news/ 0205/06/015525.htm. Diperoleh tanggal 15 Maret 2007.

Whetherall, C.F. 2006. Stops: Baca Buku Ini dan Berhenti Merokok (Alih Bahasa: Masitoh, S.). Bandung: How-Press. 
World Healh Organization. 2003. The WHO

Framework Convention on Tobacco

Control. http://www.worldbank.org/ tobacco/pdf/indonesian.pdf. Diperoleh tanggal 09 Januari 2007. 